\title{
ALK NP_004295.2:p.G1128A
}

National Cancer Institute

\section{Source}

National Cancer Institute. ALK NP 004295.2:p.G1128A. NCI Thesaurus. Code C133493.

A change in the amino acid residue at position 1128 in the ALK tyrosine kinase receptor

protein where glycine has been replaced by alanine. 